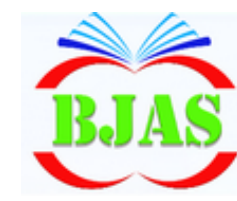

Available online at http://bajas.edu.iq

https://doi.org/10.37077/25200860.2019.271 College of Agriculture, University of Basrah

\title{
Basrah Journal of Agricultural Sciences
}

ISSN 1814 - 5868 Basrah J. Agric. Sci., 32(Spec. Issue 2): 231-245, 2019

E-ISSN: 2520-0860

\section{Efficiency of Prepared Chelate Fertilizer from Humic Acid in Reducing Ammonia Volatilization from Urea Fertilizer Ola D. AbdulSayed* \& Hayfaa J.H. Al-Tameemi}

Department of Soil Science and Water Resources,College of Agriculture, University of Basrah, Iraq

*Corresponding author e-mail oladheyaa94@ gmail.com

Received 19 September 2019; Accepted 18 November 2019; Available online 22 November 2019

\begin{abstract}
Composted cow manure sample was collected from filed of college of Agriculture, University of Basrah. Its properties were identified. Humic acid was extracted from cow manure and diagnosed according to elemental analysis (CHN), spectral study ( $\left.\mathrm{E}_{4} / \mathrm{E}_{6}\right)$, infra-red spectrum (IR), in addition to chemical composition of functional groups. Two types of humic acid were prepared, one of them humic acid with fermented plant residue (HA1-N) and other humic acid with zeolite (HA2-N). A laboratory experiment was carried out to study the amount of ammonia volatile from two prepared chelate fertilizers (HA1-N and HA2-N) and urea fertilizer by incubation two types of soils (sandy soil and clay loam soil) at $35^{\circ} \mathrm{C}$ with four rates of nitrogen $(0,125$,

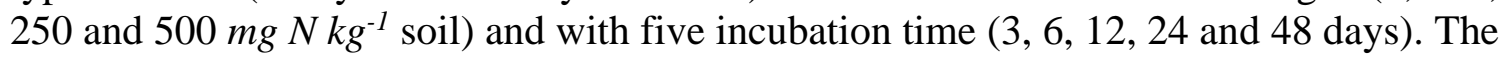
study found that increasing rate of nitrogen and incubation time increased ammonia volatilization, and the highest value was at the rate $500 \mathrm{mg} \mathrm{N} \mathrm{kg}^{-1}$ soil and at 48 days of incubation to reach a 21.427 and $9.736 \mathrm{mg} \mathrm{N}-\mathrm{NH} 3 \mathrm{Kg}^{-1}$ soil for sandy soil and clay loam soil, respectively. Application of two prepared chelate fertilizers (HA1-N and HA2-N) at rate $500 \mathrm{mg} \mathrm{N} \mathrm{Kg}^{-1}$ reduced ammonia volatilization to $99.30 \%$ and $98.62 \%$ for sandy soil and $98.96 \%$ and $97.77 \%$ for clay loam soil comparing with urea fertilizer . Fertilizers were took the following order in reducing ammonia volatilization : HA1-N > HA2-N > Urea.
\end{abstract}

Keywords: Humic acid , Ammonia volatilization, Urea fertilizer , Chelate fertilizer

\section{Introduction}

Nitrogen is one of the most important nutrient in the fertilization programs, because it is important for chlorophyll molecules synthesis, proteins, enzymes, cellular membranes, cell division and plant tolerance for extreme environmental conditions (Barker \& Bryson, 2007). Nitrogen fertilizers lead to loss when added to soils by many process like volatilization, leaching, denitrification and immobilization, which lead to low efficiency of fertilizers (Bundick et al., 2009). In order to provide continuous nitrogen for plant and increase efficiency of nitrogen fertilizers, several methods were used such as urease inhibitors, nitrification inhibitors, methods of application, slow release fertilizers and others (Prasad \& Power, 1997).

All studies had shown the important role of organic matter including humic acid in increasing nitrogen availability in soils, because its role in improving physical, chemical and biological properties of soils and their buffering capacity (Stevenson, 1982). Ahmed et al. (2006); Fan \& Mackenzie (1993) found that using of acidic 
AbdulSayed \& Al-Tameemi / Basrah J. Agric. Sci. 32(Spec. Issue 2): 231-245, 2019

substances such as humic acid reduce nitrogen losses as ammonia from fertilizers. Al-Tameemi et al. (2014) found decrease in ammonia volatilization from urea fertilizer by application of humic acid to some calcareous soils from southern Iraqi soils. Due to the lack of studies related to the effect of humic acid in nitrogen availability, the study suggested to achieve the following objectives by preparing of environmental safe chelated organic fertilizer loaded with certain proportions of nitrogen to increase its availability in soils.

\section{Materials \& Methods}

Collection of composted cow manure and determine its characteristics. A sample of composted cow manure was collected from field of College of Agriculture, University of Basrah on $19^{\text {th }}$ October, 2017, which was fermented for six months. It's initial characteristics had been identified as shown in table (1).

$\mathrm{pH}$ and electrical conductivity were measured in suspended leachate (1:5) (cow manure: distilled water) according to the methods described in Page et al. (1982). Organic matter of cow manure was determined by determination of organic carbon (Black, 1965).

Cow manure was digested according to method mentioned by Cresser \& Parsons (1979). Total nitrogen, total phosphate and total potassium were determined in digestion solution. $\mathrm{C} / \mathrm{N}$ and $\mathrm{C} / \mathrm{P}$ ratios were calculated by dividing of total carbon on total nitrogen and total carbon on total phosphate, respectively.

Table (1): Some chemical properties of cow manure.

\begin{tabular}{|c|c|c|}
\hline Property & Unit & Value \\
\hline $\mathrm{pH}(1: 5)$ & - & 7.18 \\
\hline $\begin{array}{l}\text { Electrical Conductivity } \\
\text { (EC) }(1: 5)\end{array}$ & $\mathrm{dS} \mathrm{m^{-1 }}$ & 21.50 \\
\hline Organic Matter & $\mathrm{g} \mathrm{kg}^{-1}$ & 380.50 \\
\hline Total nitrogen & & 17.98 \\
\hline Total phosphate & & 9.50 \\
\hline Total potassium & & 9.70 \\
\hline $\mathrm{C} / \mathrm{N}$ ratio & - & 12.28 \\
\hline $\mathrm{C} / \mathrm{P}$ ratio & - & 23.23 \\
\hline
\end{tabular}

\section{Preparation of humic acid}

Cow manure was collected from animal filed of the Agricultural Research Station / College of Agriculture, University of Basrah which was fermented for six months at date $19^{\text {th }}$ October, 2017. Cow manure sample was air dried and impurities were removed. It was sieved at $1 \mathrm{~mm}$ and stored in plastic containers for use in subsequent experiment.

\section{Extraction of humic acids}

Humic acids (humic acid and fulvic acid) were extracted from composted cow manure by using alkaline solution of $0.5 \mathrm{M} \mathrm{NaOH}$ according to the method mentioned in Page et al. (1982). Separation of humic acid from fulvic acid was used by concentrated acid of $\mathrm{HCl}(6 \mathrm{~N} \mathrm{HCl})$, and $\mathrm{pH}$ value of the extraction solution was adjusted to $\mathrm{pH} 1$, and it left for next day for coagulation. The humic acid 
(precipitate) was separated from fulvic acid by centrifugation at $4000 \mathrm{rpm}$, and kept each of them in plastic containers in refrigerator until is used.

\section{Purification of humic Acid}

According to the method described in Page et al. (1982) in removing clays and impurities from humic acid by using $0.1 \mathrm{M} \mathrm{KOH}$ and centrifugation and $\mathrm{pH}$ adjusted to 6 by using dilute solution of hydrochloric acid. In order to increase the efficiency of humic acid in cations sorption, humic acid treated with $\mathrm{H}$ resin and separated from it by 50 mesh sieve, and then it was adjusted to $\mathrm{pH}=6$ and kept in clean plastic containers in refrigerator.

\section{Diagnoses of humic Acid}

Humic acid was diagnosed by using elemental analysis (Carbon, hydrogen and nitrogen) by using Italian Euro EA3000. Spectrophotometry in visible region was used according to the ratio of $\mathrm{E}_{4} / \mathrm{E}_{6}$ (Page et al., 1982).

Infra-red spectrum (IR) of humic acid was measured in laboratory of College of Pharmacy, University of Basrah, by using humic acid with potassium bromide (KBr) and recording IR spectrum by using infra-red spectrum (IR) type IR Affinity-1 instrument.

\section{Chemical Composition of Humic Acid}

Total acidity, carboxylic groups, total hydroxyl, phenolic and alcoholic groups were estimated according to the methods described in Page et al. (1982). Phenolic OH groups were calculated from the following relationship (meq phenolic $\mathrm{OH}$ groups.gm ${ }^{-1}$ of Humic acid $=m e q$ total acidity.gm ${ }^{-1}$ Humic acid - meq carboxylic groups.gm ${ }^{-1}$ Humic acid).

\section{Preparation of Chelate Fertilizer HA-N}

Chelate fertilizer HA-N was prepared with two types HA1-N and HA2-N, by taking a certain amount of pure humic acid at $\mathrm{pH}=6$ and treated with a known concentration of ammonium chloride to reach nitrogen concentration 15 to $20 \%$ and adjusting $\mathrm{pH}$ value to 6. Humic acid was treated with natural materials, peat moss and fermented sawdust for HA1-N, and peat moss, fermented sawdust and zeolite for HA2-N. Nitrogen concentration of chelate fertilizers was determined by digestion fertilizers according to the method of Cresser \& Parsons (1979).

\section{Sampling and Preparation of Soils}

Two agricultural land sites were selected for experiment, one of them from Zubair site and other from Medayna site on $20^{\text {th }}$ October, 2017 at depth of 0-30 cm. Physical and chemical properties of soils were determined according to the methods mentioned in Richards (1954), Black (1965), Jackson (1973), Papanicolaou (1976), Bremner (1982), and Page et al. (1982) (Table 2).

Testing the Efficiency of Chelate Fertilizers (HA1-N and HA2-N) in Loss of Nitrogen by Volatilization

A laboratory experiment was carried out to study the efficiency of prepared chelate fertilizers (HA1-N and HA2-N) in loss of ammonia by volatilization in two calcareous soils and comparing them with urea fertilizer, nitrogen was added at four rates $(0,125,250$ and $500 \mathrm{mg} \mathrm{N} . \mathrm{Kg}^{-1}$ soil) and at five periods of incubation (3, 6, 12, 24 and 48 days). After each incubation period volatile ammonia was calculated according to the relationship : 
Table (2): Some properties of both studied soils.

\begin{tabular}{|c|c|c|c|}
\hline \multirow[t]{2}{*}{ Properties } & \multirow[t]{2}{*}{ Unit } & \multicolumn{2}{|c|}{ Value } \\
\hline & & $\begin{array}{c}\text { Zubair } \\
\text { (Sandy soil) }\end{array}$ & $\begin{array}{c}\text { Medayna } \\
\text { (Clay loam soil) }\end{array}$ \\
\hline $\mathrm{pH}(1: 1)$ & - & 7.75 & 7.45 \\
\hline $\begin{array}{r}\text { Electrical conductivity (EC) } \\
(1: 1)\end{array}$ & $\mathrm{dS} \mathrm{m}^{-1}$ & 7.00 & 3.99 \\
\hline $\begin{array}{l}\text { Cation exchange capacity } \\
\text { (CEC) }\end{array}$ & $\mathrm{Cmol} \mathrm{kg}^{-1}$ & 5.85 & 20.50 \\
\hline Organic matter & $\mathrm{gm} \mathrm{kg}^{-1}$ & 1.65 & 11.50 \\
\hline Carbonate minerals & $\mathrm{gm} \mathrm{kg}^{-1}$ & 200.00 & 287.50 \\
\hline Total nitrogen & $\mathrm{gm} \mathrm{kg}^{-1}$ & 0.10 & 1.10 \\
\hline $\mathrm{C} / \mathrm{N}$ & - & 6.09 & 7.33 \\
\hline Available nitrogen & $\mathrm{mg} \mathrm{kg}^{-1}$ & 4.20 & 20.00 \\
\hline Soluble cations & $\mathrm{mmol} \mathrm{L}^{-1}$ & & \\
\hline $\mathrm{Ca}^{+2}$ & & 8.50 & 9.00 \\
\hline $\mathrm{Mg}^{+2}$ & & 16.00 & 6.23 \\
\hline $\mathrm{Na}^{+}$ & & 15.31 & 6.00 \\
\hline $\mathrm{K}^{+}$ & & 0.865 & 1.64 \\
\hline Soluble anions & $\mathrm{mmol} \mathrm{L}^{-1}$ & & \\
\hline $\mathrm{Cl}^{-}$ & & 30.50 & 17.50 \\
\hline $\mathrm{SO}_{4}{ }^{-2}$ & & 11.50 & 5.00 \\
\hline $\mathrm{CO}_{3}{ }^{-2}$ & & 0.00 & 0.00 \\
\hline $\mathrm{HCO}_{3}{ }^{-}$ & & 15.00 & 11.50 \\
\hline Soil particles & $\mathrm{gm} \mathrm{kg}^{-1}$ soil & & \\
\hline clay & & 39.00 & 318.00 \\
\hline silt & & 41.00 & 368.00 \\
\hline sand & & 902.00 & 312.00 \\
\hline Soil texture & & Sandy & Loam clay \\
\hline
\end{tabular}

\section{Results \& Discussion}

Diagnosing of humic acid by:-

\section{Elemental analysis}

The results in table (3) showed the elemental analysis of humic acid extracted from fermented cow and its content of carbon, hydrogen, nitrogen, sulfur, oxygen and carbon to nitrogen ratio which were reached to $35.87 \%, 4.36 \%, 2.66 \%, 0,65 \%, 56.46 \%$ and $13.48 \%$, respectively. Tan (2003) pointed out that humic acid content is differed according to source of organic material (soil, water, plant, animal or plant residues, etc.), soil characteristics and conditions, and extraction solution. Al-Tameemi (1997) found that C, H,
$\mathrm{N}, \mathrm{S}$ and $\mathrm{O}$ of humic acid were $57.80 \%, 5.63$ $\%, 2.75 \%, 0.68 \%$ and $33.14 \%$, respectively. The results of this study were consistent with the results finding by several researchers such as Madhavi (2014) and Ferrara \& Brunetti (2008).

Table 3 shows the ratio of carbon to nitrogen $(\mathrm{C} / \mathrm{N}$ ratio) of humic acid which reached 13.48. Kumada (1987) pointed out that reaching of $\mathrm{C} / \mathrm{N}$ ratio value between 10 to 15 means that organic matter reaches the degree of humification.

Table (3) explained the ratio of carbon to nitrogen $(\mathrm{C} / \mathrm{N}$ ratio) of humic acid which 
AbdulSayed \& Al-Tameemi / Basrah J. Agric. Sci. 32(Spec. Issue 2): 231-245, 2019

Table (3): Elemental analysis and $\mathbf{E}_{4} / \mathbf{E}_{6}$ ratio of humic acid.

Humic acid

$\%$ for elemental

E4 / E6

\begin{tabular}{cccccc}
\hline $\mathrm{C}$ & $\mathrm{H}$ & $\mathrm{N}$ & $\mathrm{S}$ & $\mathrm{O}$ & $\mathrm{C} / \mathrm{N}$ \\
\hline 35.87 & 4.36 & 2.66 & 0.65 & 56.46 & 13.48
\end{tabular}

reached 13.48. Kumada (1987) pointed out that reaching of $\mathrm{C} / \mathrm{N}$ ratio value between 10 to 15 means that organic matter reaches the degree of humification.

$\mathrm{E}_{4} / \mathrm{E}_{6}$ ratio which represents the optical density or absorption ratio of humic acid at wave length of 465 and $665 \mathrm{~nm}$ which was 3.38 (table 3). This ratio had been used by many researchers in the identification and diagnosis of humic substances. The value of $\mathrm{E}_{4} / \mathrm{E}_{6}$ differs with the different source of humic acid and type and concentration of extraction solution (Schnitzer \& Khan, 1972), and the value of $\mathrm{E}_{4} / \mathrm{E}_{6}$ reflects the degree of condensation of ring of humic acid. The low values indicate the high degree of condensation of humic acid, while the high value of $\mathrm{E}_{4} / \mathrm{E}_{6}$ show the low degree of condensation and high concentration of aliphatic structures (Schnitzer, 1977).

\section{Infra-red Spectroscopy (IR)}

Infra-red spectra of humic acid (fig. 1) shows frequencies ranging from $524.64 \mathrm{~cm}^{-1}$ to $3417.86 \mathrm{~cm}^{-1}$, indicating that there were different groups with different structures of functional groups.

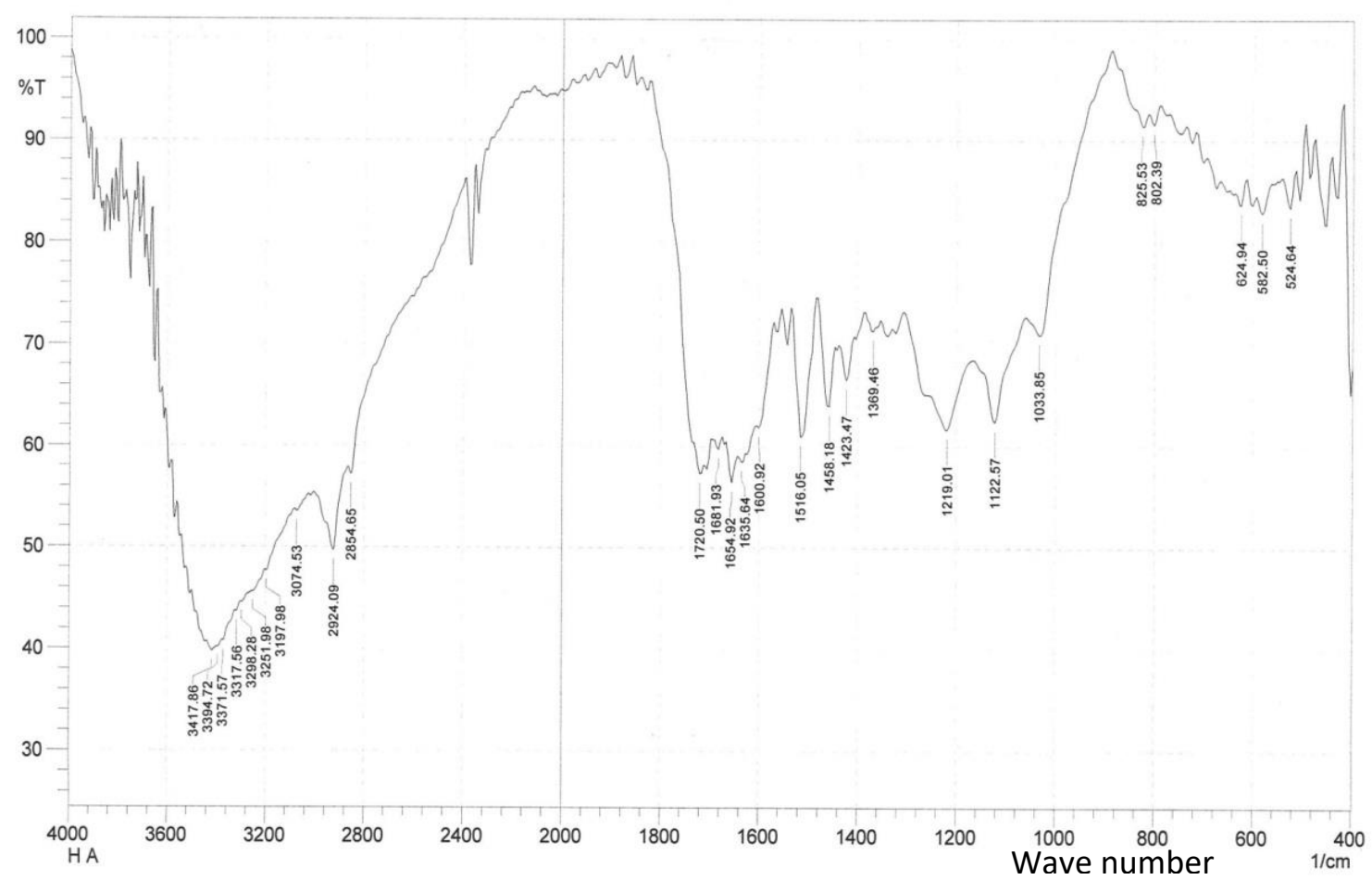

Fig. (1): Infra-red spectra of humic acid extracted from cow manure.

According to Peters et al. (1973) O-H groups predominate between 2800 to 3500 $\mathrm{cm}^{-1}$ with the dominance of amides, amines and alcoholic groups. The spectra intensity of 
AbdulSayed \& Al-Tameemi / Basrah J. Agric. Sci. 32(Spec. Issue 2): 231-245, 2019

spectrum at $2000 \mathrm{~cm}^{-1}$ indicates the presence of ring type structures $(\mathrm{C}=\mathrm{C})$. The emergence of beams at the spectrum $1720.50 \mathrm{~cm}^{-1}$ indicates the presence of compounds with $\mathrm{C}=\mathrm{O}$ and aliphatic compounds, while at 1681.93 to $1516.05 \mathrm{~cm}^{-1}$ are structures of type $\mathrm{C}=\mathrm{C}$. The spectral bands ranging from 1458.18 to $802.39 \mathrm{~cm}^{-1}$ are compounds, containing $\mathrm{C}-\mathrm{H}$, usually methyl, methylene and isopropyl.

The spectra of infrared radiation does not give the chemical composition of organic compounds but gives an idea of the nature and properties of the materials and the structure of the compounds (Stevenson, 1982). The results of IR showed the predominance of cyclic compounds $(\mathrm{C}=\mathrm{C}$ groups).

\section{Functional Groups of Humic Acid}

Table (4) revealed the results of analysis of oxygen- containing functional groups of humic acid (total acidity, carboxylic, phenolic , alcoholic and total hydroxyl groups), which reached $7.20,4.30,2.90,4.30$ and $7.20 \mathrm{meq}$ $\mathrm{gm}^{-1}$, respectively. This results in agreement with the results of Al-Tameemi (1997), Ahmed et al. (2006), Ferrara \& Brunetti (2008), Madhavi (2014) and Eshwar et al. (2017). The difference in the total acidity values of humic acid is due to the differences in the concentration of functional groups of carboxylic and phenolic groups. The high values of total acidity are evidence of ability of humic acid to adsorb nutrients, heavy metals, high cation exchange capacity and retention of water (Tan, 2003).

Table (4): Functional groups of humic acid extracted from cow manure.

\begin{tabular}{cc}
\hline Functional groups & $\begin{array}{c}\text { Value } \\
\left(\mathrm{meq}^{\mathrm{gm}^{-1}}\right)\end{array}$ \\
\hline Total acidity & 7.20 \\
\hline Carboxylic groups $\mathrm{COOH}$ & 4.30 \\
\hline Phenolic OH & 2.90 \\
\hline Alcoholic OH & 4.30 \\
\hline Total OH & 7.20 \\
\hline
\end{tabular}

Results of humic acid analysis showed that concentration of phenolic groups $(2.90 \mathrm{meq}$ $\left.\mathrm{gm}^{-1}\right)$ was less than carboxylic groups (4.30 meq $\mathrm{gm}^{-1}$ ), this explains that carbohydrate and phenolic compounds had been transformed to carboxylic groups through oxiclation process (Eshwar et al., 2017). The role of phenolic groups in the nutrients chelation is less important than carboxylic groups because of its ionization at $\mathrm{pH}>9$ (Schnitzer, 1986). Both carboxylic and phenolic groups accounted for $59.72 \%$ and $40.28 \%$ of total acidity of humic acid, respectively .
The concentration of alcoholic groups and hydroxyl groups of humic acid were 4.30 and $7.20 \mathrm{meq}_{\mathrm{gm}}^{-1}$, respectively. Al-Tameemi (1997) found that their concentration in humic acid were 4.90 and $7.35 \mathrm{meq} \mathrm{gm}^{-1}$, respectively. Alcoholic and hydroxyl groups are less important than carboxylic and phenolic groups in their reactions with colloids and nutrients because they are usually associated with side chains of humic acid (Gamble, 1988). 
AbdulSayed \& Al-Tameemi / Basrah J. Agric. Sci. 32(Spec. Issue 2): 231-245, 2019

Effect of Rate and Type of Nitrogen Fertilizer, and Time of Incubation on Ammonia Volatilization

Results in fig. 2 and 3 indicate that there were a significant differences in the amount of volatile ammonia with different nitrogen rates applied to sandy and clay loam soils. The amounts of volatile ammonia at rate 0,125 , 250 and $500 \mathrm{mg} \mathrm{N} \mathrm{kg}^{-1}$ soil were $0,2.603$, 3.776 and $8.183 \mathrm{mg} \mathrm{NH}_{3}-\mathrm{N} \mathrm{kg}^{-1}$ for sandy soil and $0.247,1.923,2.406$ and $3.696 \mathrm{mg} \mathrm{NH}_{3}-\mathrm{N}$ $\mathrm{kg}^{-1}$ for clay loam soil, respectively. These results were agreed with the results finding

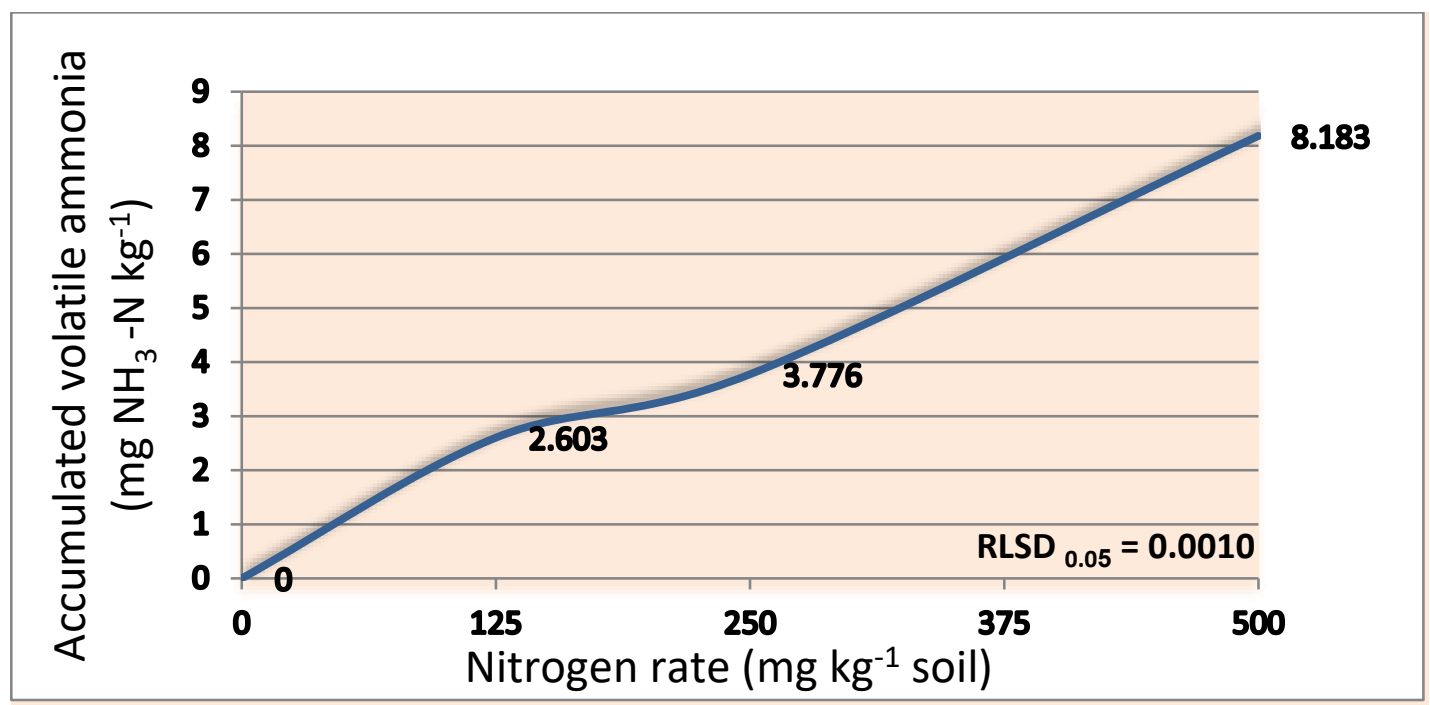

Fig. (2): Effect of nitrogen rate on accumulated ammonia volatilization in sandy soil. by Abdul-Kareem (2006), Alberto et al. (2010), Ma et al. (2010).

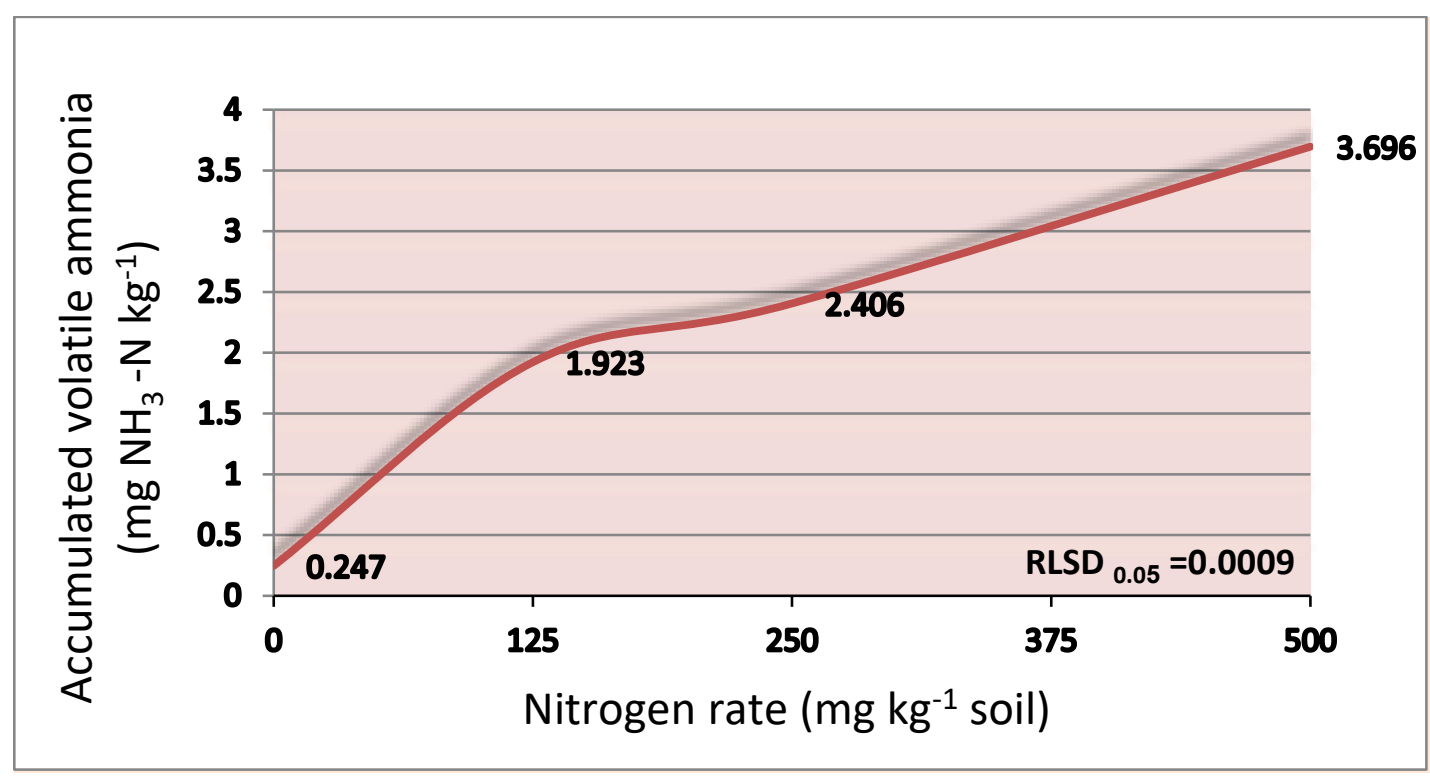

Fig. (3): Effect of nitrogen rate on accumulated ammonia volatilization in clay loam soil.

Figs. (4 and 5) revealed effect of incubation periods on ammonia volatilization in sandy and clay loam soils, respectively. The results showed a significant differences between incubation periods $(3,6,12,24$ and 48 days) to reached $0.109,1.278,3.263,4.001$ and 
AbdulSayed \& Al-Tameemi / Basrah J. Agric. Sci. 32(Spec. Issue 2): 231-245, 2019

$9.550 \mathrm{mg} \mathrm{NH}_{3}-\mathrm{N} \mathrm{kg}^{-1}$ for sandy soil and $0.019,0.071,1.185,3.269$ and $5.797 \mathrm{mg} \mathrm{NH}_{3-}$ $\mathrm{N} \mathrm{kg}^{-1}$ for clay loam soil, respectively. This is due to the increase in fertilizer hydrolysis by urease enzyme and release of nitrogen then losing a part of it by volatilization. The lowest value of volatilization was after 3 days, while the highest value was after 48 days, and ammonia volatilization was higher in sandy soil than clay loam soil.

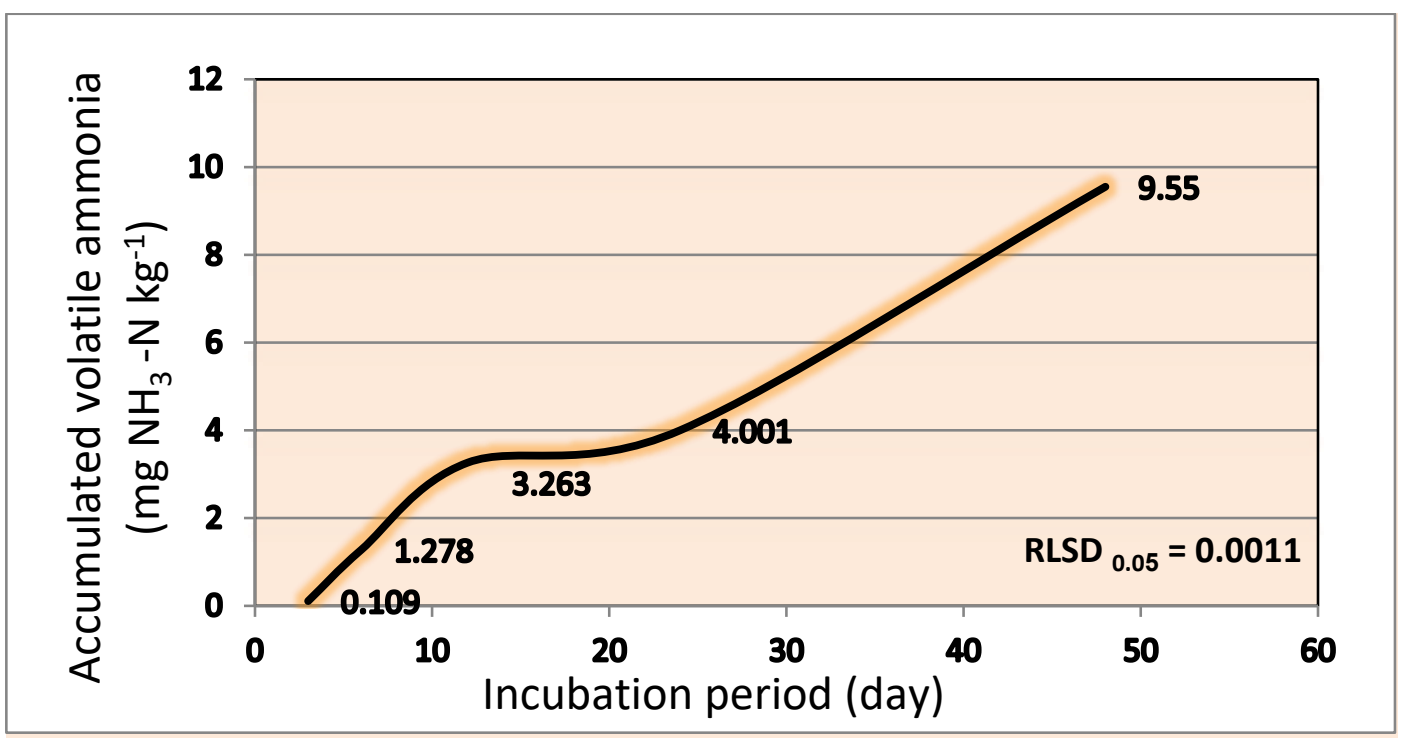

Fig. (4): Effect of incubation period on accumulated ammonia volatilization in sandy soil.

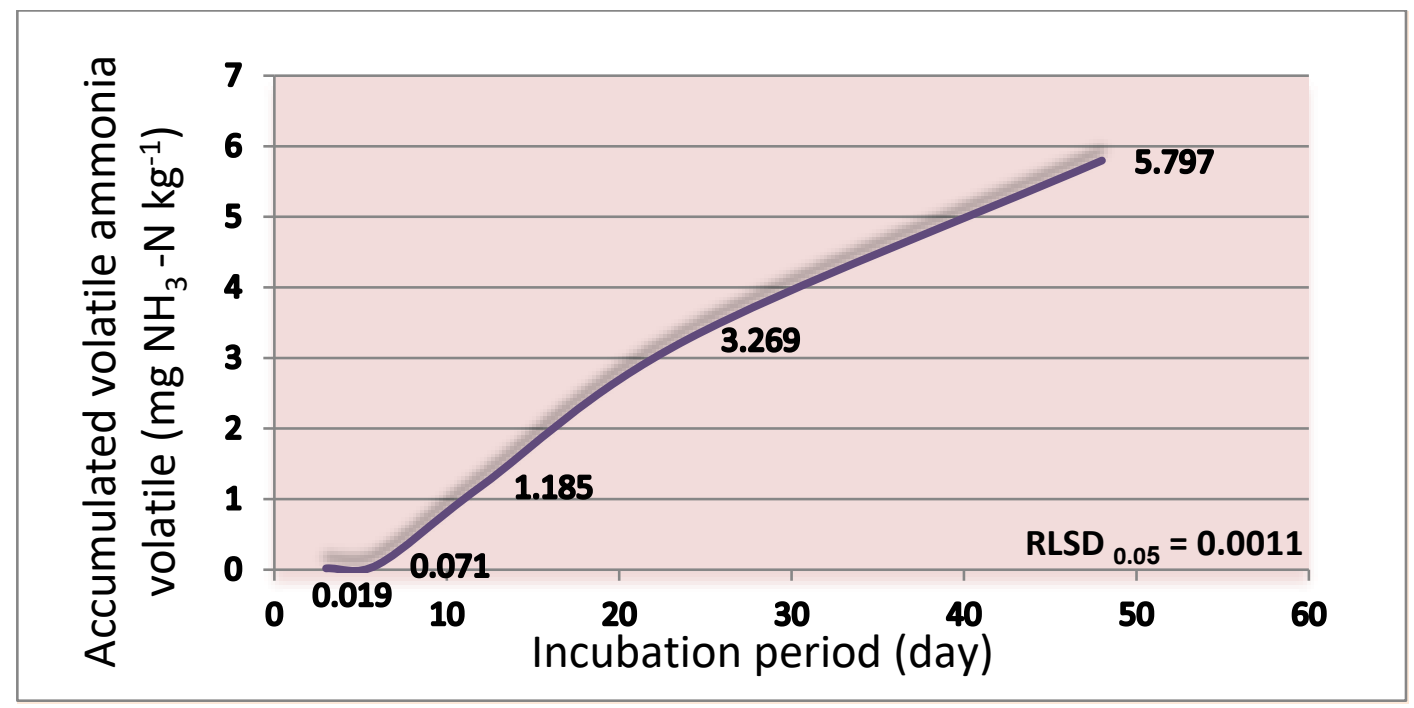

Fig. (5): Effect of incubation period on accumulated ammonia volatilization in clay loam soil.

Fig. (6 and 7) showed high significant effect of type of nitrogen fertilizer on amount of volatile ammonia for sandy and clay loam soils. It was reached $10.673,0,062$ and 0.187 $\mathrm{mg} \mathrm{NH}_{3}-\mathrm{N} \mathrm{kg}^{-1}$ soil for urea and chelate fertilizers HA1-N and HA2-N respectively for sandy soil and 6.027, 0.041 and $0.137 \mathrm{mg}$
$\mathrm{NH}_{3}-\mathrm{N} \mathrm{kg} \mathrm{kg}^{-1}$ soil for clay loam soil respectively. The decrease in the amount of volatile ammonia for two chelate humic acid fertilizers were $99.42 \%$ and $98.25 \%$ for sandy soil and $99.32 \%$ and $97.73 \%$ for clay loam soil, respectively. 
AbdulSayed \& Al-Tameemi / Basrah J. Agric. Sci. 32(Spec. Issue 2): 231-245, 2019

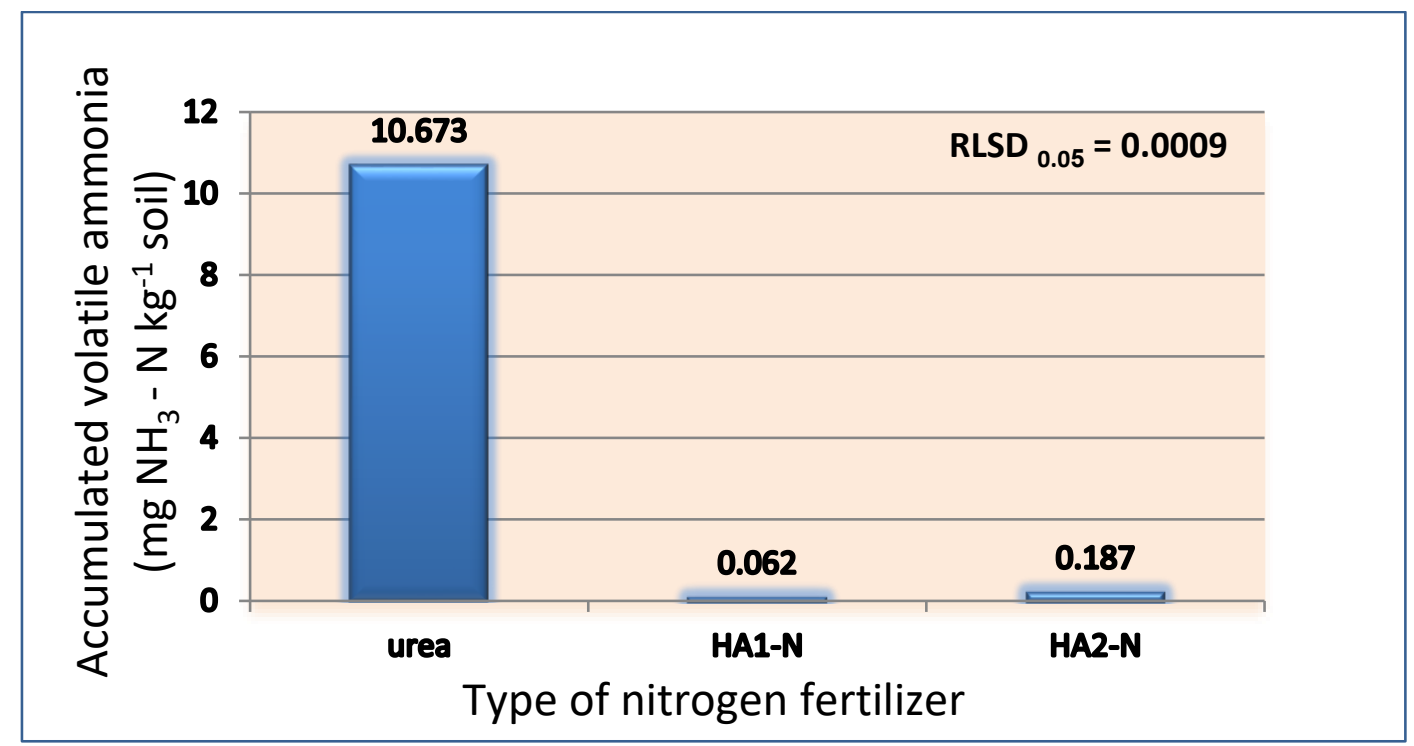

Fig. (6): Effect of type of nitrogen fertilizer on accumulated ammonia volatilization in sandy soil.

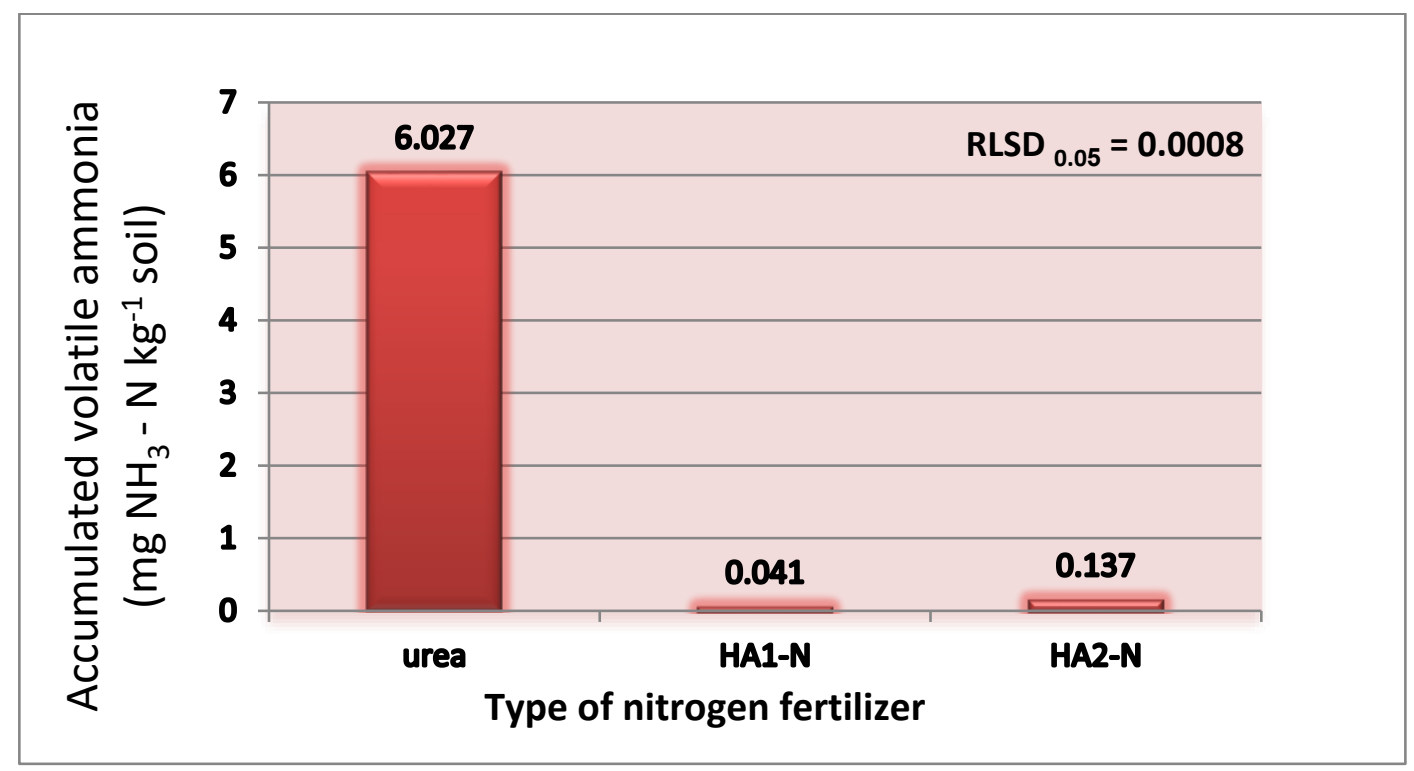

Fig. (7): Effect of type of nitrogen fertilizer on accumulated ammonia volatilization in clay loam soil.

This is due to the nature and composition of materials used in preparation of two chelate fertilizers, which are rich with functional groups which have ability to chelate and adsorb ammonium ions and reduce its loss by volatilization. These results agree with the results finding by Al-Tameemi et al. (2014). Results in tables (5 and 6) displayed the effect of interaction between rate of nitrogen fertilizer and incubation period on the amount of volatile ammonia. The highest amount of volatile ammonia was in sandy and clay loam soils after 48 days and at rate $500 \mathrm{mg} \mathrm{N} \mathrm{kg}^{-1}$ soil to reached 21.427 and $9.736 \mathrm{mg} \mathrm{NH3-} \mathrm{N}$ $\mathrm{kg}^{-1}$ soil, respectively with a significant differences between rates of nitrogen fertilizer. The results also showed (table 5 and 6) that ammonia volatilization started after 24 
AbdulSayed \& Al-Tameemi / Basrah J. Agric. Sci. 32(Spec. Issue 2): 231-245, 2019

Table (5): Effect of interaction between nitrogen fertilizer rates and incubation periods on amount of volatile ammonia (mg NH3- $\mathrm{N} \mathrm{kg}^{-1}$ soil) from sandy soil.

\begin{tabular}{|c|c|c|c|c|c|}
\hline Rate of nitrogen (mg & & $\begin{array}{l}\text { at of vo } \\
\text { NH3- }\end{array}$ & $\begin{array}{l}\text { atile an } \\
\mathrm{J} \mathrm{kg}^{-1} \mathrm{~s}\end{array}$ & $\begin{array}{l}\text { nonia } \\
\text { il) }\end{array}$ & \\
\hline $\begin{array}{l}\text { Incubation } \\
\text { periods (day) }\end{array}$ & 0 & 125 & 250 & 500 & $\begin{array}{c}\text { RLSD }_{0.05} \\
\text { (Rate of nitrogen X }\end{array}$ \\
\hline 3 & 0 & 0.112 & 0.137 & 0.187 & Incubation periods) \\
\hline 6 & 0 & 0.663 & 1.605 & 2.843 & \\
\hline 12 & 0 & 1.725 & 3.533 & 7.794 & \\
\hline 24 & 0 & 3.423 & 3.920 & 8.663 & \\
\hline 48 & 0 & 7.090 & 9.682 & 21.427 & \\
\hline
\end{tabular}

Table (6): Effect of interaction between nitrogen fertilizer rates and incubation periods on amount of volatile ammonia (mg NH3- $\mathrm{N} \mathrm{kg}^{-1}$ soil) from clay loam soil.

\begin{tabular}{|c|c|c|c|c|c|}
\hline \multirow{2}{*}{$\begin{array}{l}\text { Rate of nitrogen }(\mathrm{mg} \\
\left.\mathrm{kg}^{-1}\right) \\
\text { periods (day) }\end{array}$} & \multicolumn{4}{|c|}{$\begin{array}{l}\text { Amount of volatile ammonia } \\
\left(\mathrm{mg} \mathrm{NH} 3-\mathrm{N} \mathrm{kg}^{-1} \text { soil }\right)\end{array}$} & \multirow{7}{*}{$\begin{array}{c}\text { RLSD }_{0.05} \\
\text { (Rate of nitrogen X Incubation } \\
\text { periods) }\end{array}$} \\
\hline & 0 & 125 & 250 & 500 & \\
\hline 3 & 0 & 0 & 0 & 0.075 & \\
\hline 6 & 0 & 0 & 0.071 & 0.214 & \\
\hline 12 & 0 & 1.287 & 1.344 & 2.108 & \\
\hline 24 & 0.500 & 2.935 & 3.292 & 6.349 & \\
\hline 48 & 0.733 & 5.395 & 7.322 & 9.736 & \\
\hline \multicolumn{5}{|c|}{ RLSD $_{0.05}$ (Rate of nitrogen X Incubation periods) } & 0.0021 \\
\hline
\end{tabular}

days in clay loam soil for control treatment, while no volatilization occurred until 48 days in sandy soil. This is due to the properties of both studied soils (Table 2). Application of nitrogen fertilizer encouraged ammonia volatilization in sandy soil at higher rate than clay loam soil, especially at the rate of 500 $\mathrm{mg} \mathrm{N} \mathrm{kg}{ }^{-1}$ soil due to ability of clay loam soil to adsorb and held of ammonium and reduce its loss by volatilization. Tables (7 and 8) showed a significant effect of interaction between type of nitrogen fertilizer and its rate on ammonia volatilization from both studied soils. The highest amount of volatile ammonia from urea fertilizer at $500 \mathrm{mg} \mathrm{N} \mathrm{kg}^{-1}$ soil reached in sandy soil $24.050 \mathrm{mg} \mathrm{NH3}-\mathrm{N} \mathrm{kg}^{-1}$ soil and clay loam soil $10.738 \mathrm{mg} \mathrm{NH} 3-\mathrm{N} \mathrm{kg}^{-}$ ${ }^{1}$ soil, while the lowest values were achieved with HA1-N at rate $500 \mathrm{mg} \mathrm{N} \mathrm{kg}^{-1}$ soil to reached $0.168 \mathrm{mg} \mathrm{NH} 3-\mathrm{N} \mathrm{kg}^{-1}$ soil for sandy soil and $0.112 \mathrm{mg} \mathrm{NH} 3-\mathrm{N} \mathrm{kg}^{-1}$ soil for clay loam. The per cents of decrease in the amount of ammonia volatile at rate $500 \mathrm{mg} \mathrm{N} \mathrm{kg}^{-1}$ soil for HA1-N and HA2-N fertilizers as compared with urea fertilizer in sandy soil were $99.30 \%$ and $98.62 \%$, respectively and $98.96 \%$ and $97.77 \%$ for clay loam soil, respectively. Fertilizers were taken the 
AbdulSayed \& Al-Tameemi / Basrah J. Agric. Sci. 32(Spec. Issue 2): 231-245, 2019

Table (7) : Effect of interaction between type of nitrogen fertilizer and its rate on the amount of volatile ammonia in sandy soil.

\begin{tabular}{|c|c|c|c|c|}
\hline \multirow{2}{*}{$\begin{array}{l}\text { Type of nitrogen fertilizer } \\
\text { Rate of } \\
\text { nitrogen }\left(\mathrm{mg} \mathrm{kg}^{-4}\right)\end{array}$} & \multicolumn{3}{|c|}{$\begin{array}{c}\text { Amount of volatile ammonia } \\
\left(\mathrm{mg} \mathrm{NH} 3-\mathrm{N} \mathrm{kg}^{-1} \text { soil }\right)\end{array}$} & \multirow{6}{*}{$\begin{array}{c}\text { RLSD }_{0.05} \\
\text { (Type of nitrogen fertilizer X } \\
\text { Rate of nitrogen) }\end{array}$} \\
\hline & Urea & $\begin{array}{c}\text { HA1- } \\
\mathrm{N}\end{array}$ & HA2-N & \\
\hline 0 & 0 & 0 & 0 & \\
\hline 125 & 7.627 & 0 & 0.180 & \\
\hline 250 & 11.014 & 0.078 & 0.235 & \\
\hline 500 & 24.050 & 0.168 & 0.331 & \\
\hline \multicolumn{4}{|c|}{ RLSD $_{0.05}$ (Type of nitrogen fertilizer X Rate of nitrogen) } & 0.0018 \\
\hline
\end{tabular}

Table (8): Effect of interaction between type of nitrogen fertilizer and its rate on the amount of volatile ammonia in clay loam soil.

\begin{tabular}{|c|c|c|c|c|}
\hline \multirow{2}{*}{$\begin{array}{l}\text { Type of nitrogen fertilizer } \\
\text { Rate of } \\
\text { nitrogen }\left(\mathrm{mg} \mathrm{kg}^{-1}\right)\end{array}$} & \multicolumn{3}{|c|}{$\begin{array}{l}\text { Amount of volatile ammonia } \\
\left(\mathrm{mg} \mathrm{NH} 3-\mathrm{N} \mathrm{kg}^{-1} \text { soil }\right)\end{array}$} & \multirow{6}{*}{$\begin{array}{c}\text { RLSD }_{0.05} \\
\text { (Type of nitrogen fertilizer X } \\
\text { Rate of nitrogen) }\end{array}$} \\
\hline & Urea & HA1-N & HA2-N & \\
\hline 0 & 0.740 & 0 & 0 & \\
\hline 125 & 5.645 & 0 & 0.125 & \\
\hline 250 & 6.983 & 0.052 & 0.183 & \\
\hline 500 & 10.738 & 0.112 & 0.239 & \\
\hline \multicolumn{4}{|c|}{ RLSD 0.05 (Type of nitrogen fertilizer X Rate of nitrogen) } & 0.0016 \\
\hline
\end{tabular}

following order in reducing the amount of volatile ammonia: HA1-N > HA2-N > Urea. Results in tables (9 and 10) indicated the significant effect of interaction between type of nitrogen fertilizer and incubation periods

Table (9): Effect of interaction between type of nitrogen fertilizer and incubation periods on the amount of volatile ammonia in sandy soil.

\begin{tabular}{|c|c|c|c|c|}
\hline \multirow{2}{*}{$\begin{array}{l}\text { Type of nitrogen fertilizer } \\
\text { Incubation } \\
\text { periods (day) }\end{array}$} & \multicolumn{3}{|c|}{$\begin{array}{l}\text { Amount of volatile ammonia } \\
\left(\mathrm{mg} \mathrm{NH} 3-\mathrm{N} \mathrm{kg}^{-1} \text { soil }\right)\end{array}$} & \multirow{7}{*}{$\begin{array}{c}\text { RLSD }_{0.05} \\
\text { (Type of nitrogen } \\
\text { fertilizer X } \\
\text { Incubation periods ) }\end{array}$} \\
\hline & Urea & HA1-N & HA2-N & \\
\hline 3 & 0.327 & 0 & 0 & \\
\hline 6 & 3.815 & 0 & 0.019 & \\
\hline 12 & 9.567 & 0.036 & 0.187 & \\
\hline 24 & 11.588 & 0.072 & 0.345 & \\
\hline 48 & 28.067 & 0.201 & 0.382 & \\
\hline RLSD $_{0.05}$ (Type of nitroge & tilizer X & cubatio & riods) & 0.0020 \\
\hline
\end{tabular}


AbdulSayed \& Al-Tameemi / Basrah J. Agric. Sci. 32(Spec. Issue 2): 231-245, 2019

Table (10): The effect of interaction between type of nitrogen fertilizer and incubation periods on the amount of volatile ammonia for clay loam soil.

\begin{tabular}{|c|c|c|c|c|}
\hline \multirow{2}{*}{$\begin{array}{l}\text { Type of nitrogen fertilizer } \\
\text { Incubation } \\
\text { periods (day) }\end{array}$} & \multicolumn{3}{|c|}{$\begin{array}{l}\text { Amount of volatile ammonia } \\
\left(\mathrm{mg} \mathrm{NH} 3-\mathrm{N} \mathrm{kg}^{-1} \text { soil }\right)\end{array}$} & \multirow{7}{*}{$\begin{array}{c}\text { RLSD } 0.05 \\
\text { (Type of nitrogen } \\
\text { fertilizer X } \\
\text { Incubation periods ) }\end{array}$} \\
\hline & Urea & HA1-N & HA2-N & \\
\hline 3 & 0.056 & 0 & 0 & \\
\hline 6 & 0.208 & 0 & 0.006 & \\
\hline 12 & 3.419 & 0 & 0.135 & \\
\hline 24 & 9.561 & 0 & 0.247 & \\
\hline 48 & 16.890 & 0.206 & 0.294 & \\
\hline \multicolumn{4}{|c|}{ RLSD $_{0.05}$ (Type of nitrogen fertilizer X Incubation periods) } & 0.0018 \\
\hline
\end{tabular}

Table (11): Effect of interaction between type of nitrogen fertilizer, its rate and incubation period on ammonia volatilization in sandy soil.

\begin{tabular}{|c|c|c|c|c|c|c|}
\hline \multirow{3}{*}{$\begin{array}{l}\text { Type of } \\
\text { nitrogen } \\
\text { fertilizer }\end{array}$} & \multirow{3}{*}{$\begin{array}{c}\text { Incubation } \\
\text { periods (day) }\end{array}$} & \multicolumn{4}{|c|}{ Amount of volatile ammonia } & \multirow{18}{*}{$\begin{array}{c}\text { RLSD } 0.05 \\
\text { (Type of nitrogen } \\
\text { fertilizer X } \\
\text { Incubation periods } \\
\text { X Rate of nitrogen) }\end{array}$} \\
\hline & & \multicolumn{4}{|c|}{ Rate of nitrogen $\left(\mathrm{mg} \mathrm{kg}^{-1}\right)$} & \\
\hline & & 0 & 125 & 250 & 500 & \\
\hline \multirow[t]{5}{*}{ Urea } & 3 & 0 & 0.336 & 0.412 & 0.560 & \\
\hline & 6 & 0 & 1.990 & 4.816 & 8.456 & \\
\hline & 12 & 0 & 4.947 & 10.360 & 22.960 & \\
\hline & 24 & 0 & 9.953 & 11.312 & 25.088 & \\
\hline & 48 & 0 & 20.911 & 28.170 & 63.186 & \\
\hline \multirow[t]{5}{*}{ HA1-N } & 3 & 0 & 0 & 0 & 0 & \\
\hline & 6 & 0 & 0 & 0 & 0 & \\
\hline & 12 & 0 & 0 & 0 & 0.143 & \\
\hline & 24 & 0 & 0 & 0 & 0.286 & \\
\hline & 48 & 0 & 0 & 0.392 & 0.411 & \\
\hline \multirow[t]{5}{*}{ HA2-N } & 3 & 0 & 0 & 0 & 0 & \\
\hline & 6 & 0 & 0 & 0 & 0.075 & \\
\hline & 12 & 0 & 0.229 & 0.240 & 0.280 & \\
\hline & 24 & 0 & 0.315 & 0.448 & 0.616 & \\
\hline & 48 & 0 & 0.358 & 0.485 & 0.685 & \\
\hline \multicolumn{6}{|c|}{ RLSD $_{0.05}$ (Type of nitrogen fertilizer X Incubation periods X Rate of nitrogen) } & 0.0039 \\
\hline
\end{tabular}

on the amount of volatile ammonia in two studied soils. The results show that increasing the incubation periods increase the amount of volatile ammonia due to increase in fertilizers hydrolysis. Ammonia volatilization from urea fertilizer was started after three days in both soils, but it was started after six days for sandy soil and after 24 days for clay loam soil 
AbdulSayed \& Al-Tameemi / Basrah J. Agric. Sci. 32(Spec. Issue 2): 231-245, 2019

for HA1-N. The highest values of ammonia volatilization was started after 48 days for urea to reached $28.067 \mathrm{mg} \mathrm{NH3}-\mathrm{N} \mathrm{kg}^{-1}$ soil in sandy soil and $16.890 \mathrm{mg} \mathrm{NH} 3-\mathrm{N} \mathrm{kg}^{-1}$ soil for clay loam soil.

Results in tables (11 and 12) demonstrated the significant effect between type of nitrogen fertilizer and its rate and incubation periods on the amount of volatile ammonia in two studied soils. Ammonia volatilization was begun after three days of incubation from urea in sandy soil, and ammonia volatilization increased with increasing of nitrogen rate, while ammonia volatilization was started after 12 days of incubation for HA1-N and after 6 and 3 days at rates 250 and $500 \mathrm{mg} \mathrm{N} \mathrm{kg}^{-1}$ soil from urea for clay loam soil, respectively. HA1-N didn't volatile ammonia at $125 \mathrm{mg} \mathrm{N}$ $\mathrm{kg}^{-1}$ soil till 48 days of incubation in both studied soils. Ammonia volatilization was higher in sandy soil than clay loam soil at all rates of nitrogen and all types of fertilizers and incubation periods (table 11 and 12).

Table (12): Effect of interaction between type of nitrogen fertilizer, its rate and incubation period on ammonia volatilization in clay loam soil.

\begin{tabular}{|c|c|c|c|c|c|c|}
\hline \multirow[t]{2}{*}{$\begin{array}{l}\text { Type of } \\
\text { nitrogen } \\
\text { fertilizer }\end{array}$} & \multirow[t]{2}{*}{$\begin{array}{c}\text { Incubation } \\
\text { periods } \\
\text { (day) }\end{array}$} & \multicolumn{4}{|c|}{$\begin{array}{c}\text { Amount of volatile ammonia } \\
\left(\mathrm{mg} \text { NH3- } \mathrm{N} \mathrm{kg}^{-1} \text { soil }\right)\end{array}$} & \multirow{17}{*}{$\begin{array}{c}\text { RLSD } 0.05 \\
\text { (Type of nitrogen } \\
\text { fertilizer X } \\
\text { Incubation periods } \\
\text { X Rate of nitrogen) }\end{array}$} \\
\hline & & 0 & 125 & 250 & 500 & \\
\hline \multirow[t]{5}{*}{ Urea } & 3 & 0 & 0 & 0 & 0.224 & \\
\hline & 6 & 0 & 0 & 0.212 & 0.618 & \\
\hline & 12 & 0 & 3.725 & 3.850 & 6.100 & \\
\hline & 24 & 1.500 & 8.580 & 9.542 & 18.620 & \\
\hline & 48 & 2.200 & 15.920 & 21.310 & 28.130 & \\
\hline \multirow[t]{5}{*}{ HA1-N } & 3 & 0 & 0 & 0 & 0 & \\
\hline & 6 & 0 & 0 & 0 & 0 & \\
\hline & 12 & 0 & 0 & 0 & 0 & \\
\hline & 24 & 0 & 0 & 0 & 0 & \\
\hline & 48 & 0 & 0 & 0.261 & 0.561 & \\
\hline \multirow[t]{5}{*}{ HA2-N } & 3 & 0 & 0 & 0 & 0 & \\
\hline & 6 & 0 & 0 & 0 & 0.025 & \\
\hline & 12 & 0 & 0.135 & 0.182 & 0.224 & \\
\hline & 24 & 0 & 0.225 & 0.335 & 0.428 & \\
\hline & 48 & 0 & 0.265 & 0.396 & 0.516 & \\
\hline \multicolumn{6}{|c|}{$\begin{array}{c}\text { RLSD }_{0.05 \text { (Type of nitrogen fertilizer X Incubation periods X }} \\
\text { Rate of nitrogen) }\end{array}$} & 0.0036 \\
\hline
\end{tabular}

\section{Conclusions}

The improvement of two kinds of chelated fertilizer from humic acid derived from cattle manure, one of them was humic acid with composted plant residues (HA1-N) and the other was humic acid with zeolite mineral (HA2-N) with different $\mathrm{N}$ ratios can significantly reduce nitrogen volatilization as compared with urea fertilizer. 


\section{Acknowledgments}

We would like to thank the Department of soil sciences and water resources, College of Agriculture University of Basrah for providing space and resources and scientific for this research.

\section{References}

Abdulkareem, M.A. (2006). Role of some plant extracts on urease activity, urea transformations in soils, and barley growth. Ph. D. Thesis, Coll. Agric., Univ. Basrah: 211pp.

Ahmed, O.H.; Aminuddin, H. \& Husni, M.H.A. (2006). Effects of urea, humic acid and phosphate interactions in fertilizer microsites on ammonia volatilization and soil ammonium and nitrate contents. Int. J. Agric. Res., 1(1): 25-31.

Alberto, C.C.B.; Mota, E.P.; Souza, S.C.H.; Cardoso, R.D. \& Oliviera, P.P.A. (2010). Ammonia volatilization, dry matter yield and nitrogen levels of Italian ryegrass fertilized with urea and zeolite. $19^{\text {th }}$ World Congress of Soil Sci., Soil Solutions for a Changing World. 1-6 August, Brisbane, Australia.

Al-Tameemi, H.J. (1997). The chemical behavior of artificial trace elements chelate producing from humic acids and common fertilizers and their efficiency in some calcareous soils. M. Sc. Thesis, Coll. Agric., Univ. Basrah: 203pp.

Al-Tameemi, H.J.; Ashoor, N.I. \& Al-Auqbi, S.J. (2014). Effect of humic acid on ammonia volatilization from some calcareous soils. Int. J. Bioflux Soc., 6(3): 163-168.

Barker, A.V. \& Bryson, G.M. (2007). Nitrogen. 21-50. In: Barker, A.V. \&
Pilbeam, D.J. (Eds.). Handbook of Plant Nutrition. CRC Press. 773pp.

Black, C.A. (1965). Methods of soil analysis. American Society of Agronomy, Inc. Pub. Madison, Wisconsin: 1572pp.

Bremner, J.M. (1982). Regular Kjeldahl Methods. 11-33. In: Page, A.L.; Miller, R.H. \& Keeney, D.R. (Eds.). Methods of soil analysis Part (2). $2^{\text {nd }}$ ed. ASA. Inc. Madison, Wisconsin: 1158pp.

Bundick, H.; Bruulsema, T.; Hunter, M.; Lawrence, J.; Czymmek, K. \& Ketterings, Q. (2009). Enhanced efficiency nitrogen sources. Agronomy Fact Sheet Series (Fact Sheet 45). 2pp. http://nmsp.cals.cornell.edu/publications/fa ctsheets/factsheet45.pdf.

Cresser, M.S. \& Parsons, J.W. (1979). Sulfuric -perchloric acid digestion of plant material for the determination of nitrogen, phosphorus, potassium, calcium and magnesium. Anal. Chim. Acta, 109(2): 431-436.

Eshwar, M.; Srilatha, M.; Rekha, K.B. \& Sharma, H.K. (2017). Characterization of humic substances by functional groups and spectroscopic methods. Int. J. Curr. Microbiol. App. Sci., 6(10): 1768-1774.

Fan, M.X. \& Mackenzie, A.F. (1993). Urea and phosphate interactions in fertilizer microsites: Ammonia volatilization and $\mathrm{pH}$ changes. Soil Sci. Soc. Am. J., 57: 839845 .

Ferrara, G. \& Brunetti, G. (2008). Influence of foliar applications of humic acids on yield and fruit quality of table grape cv. Italia. J. Int. des Sciences de la Vigne et du Vin, 42(2): 79-87. 
Gamble, S.D. (1988). Atrazine hydrolysis in aqueous suspensions of humic acid at 25.0 C. Can. J. Chem., 66(10): 2605 - 2617.

Jackson, M.L. (1973). Soil Chemical Analysis. Prentice. Hall of Indian Private limited, New Delhi: 214pp.

Kumada K. (1987). Chemistry of Soil Organic Matter. Elsevier, 17: 240pp.

Ma, B.L.; Wu, T.Y.; Tremblay, N.; Deen, W.; McLaughlin, N.B.; Morrison, M.J. \& Stewart, G. (2010). On-farm assessment of the amount and timing of nitrogen fertilizer on ammonia volatilization. Agronomy J., 102(1): 134-144.

Madhavi, P. (2014). Effect of biochar and humic acid of fertilizer use and yield of maize (Zea mays L.) in alfisols of southern Telangana region of andhrapradesh. M. Sc. Thesis, Coll. Agric. Univ. Rajendranagar, Hyderabad: 366pp.

Page, A.L.; Miller, R.H. \& Keeney, D.R. (1982). Methods of Soil Analysis. Part 2, $2^{\text {nd }}$ edn. Agron. 9, Pub. Madison Wisconsin: 1158pp.

Papanicolaou, E.P. (1976). Determination of cation exchange capacity of calcareous soils and their percent base saturation. Soil Sci., 121: 65 -71.

Peters, C.D.; Zion, M.S. \& Wood, E.F. (1973). A soil vegetation atmosphere transfer scheme for modeling spatially variable water and energy balance processes. J. Geophys. Res., 102: 43034324.

Prasad, R. \& Power, J.F. (1997). Soil Fertility Management for Sustainable Agriculture. Boca Raton. New York: 384pp.

Richards, L.A. (1954). Diagnosis and Improvement of Saline and Alkali Soils. Agric. Handbook No. 60. U. S. Dept. Agric. Washington D. C.: 160pp.

Schnitzer, M. (1977). Recent findings on the characterization of humic substances extracted from soils from widely differing climatic zones. In Soil Org. Matter Stud.. Int. Atomic Energy Agency, Vienna, II: 117-132.

Schnitzer, M. (1986). Organic Matter Characterization. 581- 594. In: Page A.L.; Miller, R.H. \& Keeney, D.R. (Eds.). Methods of Soil Analysis. Part 2. Chemical and Microbiological Properties. $2^{\text {nd }}$ edn. Soil Sci. Soc. Am., Madison: 1158pp.

Schnitzer, M. \& Khan, S.U. (1972). Humic substances in the environment. Marcel Dekker, New York.: 327pp.

Stevenson, F.J. (1982). Humus Chemistry. Genesis. John Wiley \& Sons, New York: 512/ 443pp.

Tan, K.H. (2003). Humic Matter in Soil and Environment. Principles and Controversies, Marcel Dekker, Inc., New York: 495pp. 